\title{
INTERCULTURAL COMMUNICATION AND CULTURAL TRANSFERS IN THE COLONIAL CONTEXT THE ENCOUNTER BETWEEN PIZARRO AND ATAHUALPA IN 1532 AND ITS DISCURSIVE REPRESENTATIONS IN EARLY- MODERN CULTURES
}

LÜSEBRINK, Hans-Jürgen ${ }^{1}$

\begin{abstract}
This contribution treats the historical representations of the encounter between the Inca King Atahualpa and the Spanish conquistador Francisco Pizarro on november $16^{\text {th }}, 1532$, in the Peruvian town of Cajamarca which was one of the decisive turning points of the Spanish conquest of South America. After theoretical and methodological reflections on the relations between intercultural communication processes and cultural transfers in the context of the conquista, it focuses first on the various contemporary Spanish discourses on the event of November $16^{\text {th }}, 1532$, which represented predominantly an official ideological version of it. In a further step are analyzed the new $18^{\text {th }}$-century discourses, influenced by different historical sources, like the work of Inca Garcilaso de la Vega, which reveal very different 'constructions', based on a transcultural network of cultural transfers and intercultural mediators, of this event.
\end{abstract}

KEYWORDS : intercultural communication ; colonial context ; Conquista, translation ; intercultural mediator ; cultural 'broker.'

\section{COMMUNICATION INTERCULTURELLE ET TRANSFERTS CULTURELS DANS LE CONTEXTE COLONIAL LA RENCONTRE ENTRE PIZARRO ET ATAHUALPA EN 1532 ET SES REPRÉSENTATIONS DISCURSIVES DANS LES CULTURES DE L'ÉPOQUE MODERNE}

\footnotetext{
${ }^{1}$ Seniorprofessur für Romanische Kulturwissenschaft und Interkulturelle Kommunikation, Universität des Saarlandes (Université de la Sarre), Allemagne.

Jangada | ano 9, nr. 17, jan/jun, 2021 | ISSN 2317-4722

242 |P á g i n a
} 


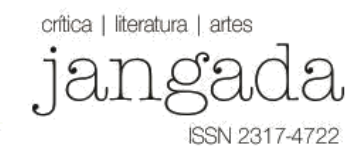

RÉSUMÉ : Cette contribution aborde la question des représentations historiques de la rencontre entre le Roi des Incas Atahualpa et le conquérant espagnol Francisco Pizarro le 16 novembre 1532 dans la ville péruvienne de Cajamarca, qui a constitué un des tournants essentiels de la conquête de l'Amérique du Sud par les Espagnols. Après des réflexions théoriques et méthodologiques sur les relations entre processus de communication interculturelle et transferts culturels dans le contexte de la Conquista, l'analyse se focalise sur les différents discours espagnols commentant l'événement du 16 novembre 1532 qui en ont offert de façon prédominante une version idéologique officielle. Dans une étape suivante sont analysés les nouveaux discours parus au 18e siècle, influencés par différentes sources historiques comme par exemple l'œuvre de l'Inca Garcilaso de la Vega, qui mettent en lumière des 'constructions' de cet événement basées sur un réseau transculturel de transferts culturels et d'intermédiaires interculturels.

MOTS-CLÉS : communication interculturelle ; contexte colonial ; Conquista ; traduction ; intermédiaire culturel ; 'broker' culturel.

\section{INTERCULTURAL COMMUNICATION PROCESSES AND CULTURAL TRANSFERS IN THE CONQUISTA}

The 'discovery' and the conquest of the Americas by the European colonial powers, and especially in its first period, by Spain and Portugal, was a violent military and political, but also cultural process with long-term effects. It included the project to eradicate indigenous languages, cultures and religions and to assimilate as far as possible the indigenous populations to European, and in the case of South America, mainly Spanish and Portuguese languages and cultures and to the Catholic religion. Spanish and Portuguese became the official languages of the vast newly conquered territories and Catholic Christianity the only religion officially accepted and tolerated. Accompanied by the transfer of cultural practices (like the Catholic mass and Catholic rituals), objects (like religious and administrative prints) and institutions (like the Catholic Church and the colonial administration), this extensive, and also in many ways violent assimilationist policy by the colonial powers was nonetheless frequently subverted by multiple and complex forms of intercultural hybridization and syncretism. Such examples of subversion and transformation have been studied in numerous case studies especially by 


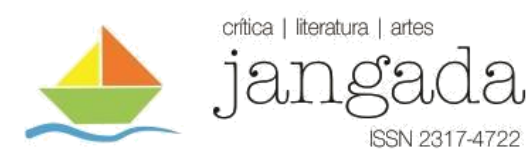

scholars like the French historian Serge Gruzinski ${ }^{2}$ and the Argentine anthropologist Néstor García Canclini (1990).

Another less analyzed dimension of intercultural processes in the context of conquest and colonization concerns the processes of intercultural communication and interaction that occurred between the European conquerors and their indigenous counterparts. These intercultural communication processes embrace a wide range of situations, forms and media. Most notably, they concern the first encounters between Europeans and indigenous people during the 'discovery' and the 'conquest' of the Americas, as illustrated by such famous pictural illustrations and engravings as 'Columbus landing on Hispaniola' on October $12^{\text {th }}, 1492$, by Theodor de Bry. ${ }^{3}$ But they also embrace other everyday situations in the colonial context: for instance, the sermons of Christian missionaries trying to convert indigenous people ${ }^{4}$, the didactic interaction in schools attended by indigenous scholars that included complex translation processes, as well as the multiple forms of communication between indigenous people and the colonial respective administration. ${ }^{5}$ The forms and media used in intercultural communication processes during the colonial era range from the predominant oral forms, accompanied by the use of gestual and mimetic signs, to written communication, print media and the recourse to icons and images which often supplemented oral or written forms of communication.

\footnotetext{
${ }^{2}$ See for example: GRUZINSKI, Serge. Visions indiennes, visions baroques. Les métissages de l'inconscient. Paris: PUF, 1992; London: Routledge, 2002. The Mestizo Mind: The Intellectual Dynamics of Colonization and Globalization.

${ }^{3}$ DE BRY, Theodor. Kolumbus wird, als er zum ersten mal in Indien angekommen ist, von den Einwohnern mit großen Geschenken verehret und begabet aufgenommen. Engraving on copper, 1594 ("Columbus landing on Hispaniola"). (https://commons.wikimedia.org/wiki/File:Columbus_landing_on_Hispaniola_adj.jpg").

${ }^{4}$ See on this point my study on the Johann Baegert, a Jesuit missionary on the California peninsula in the mid 18th-century: LÜSEBRINK, Hans-Jürgen. Comprehensión y malentendidos interculturales en las obras de Baegert (Noticias de la península americana California) y Dobrizhoffer (Historia de los Abipones). In: KOHUT, Karl; TORALES PACHECO, María Cristina (eds.). Desde los confines de los imperios ibericos. Los jesuitas de habla alemana en las misiones americanas. Frankfurt, Vervuert-Verlag/ Madrid: IberoamericanaVerlag, 2007, p. 377-394.

${ }^{5}$ See on this point for example the research project headed by Martina Schrader-Kniffki (University of Mainz, Germany) in the context of the collaborative project SPP 2130 "Early Modern Translation cultures (1450-1800)" which concerns communication and translation processes in Southern New Spain (region of Oaxaca) during the colonial period ("Colonial Translation Practices in the Periphery of New Spain between Evangelisation and Local Indigenous Jurisdiction in Spanish and Zapotec Language ( $16^{\text {th }}$ and $17^{\text {th }}$ Centuries)". See https://www.spp2130.de
} 


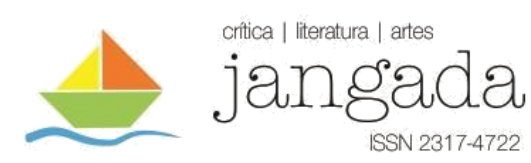

The present contribution will focus on the forms of intercultural communication during the very first encounters between the Spanish conquistadores and the representatives of the indigenous powers. These encounters represent oral forms of communication where ritual practices (like the presentation of gifts and other objects) and the symbolic role of gestures play an important part. The analysis will in a first step focus on the 'transcriptions' or, more precisely, the 'representations' in contemporary Spanish chronicles and historiographies of one such historical event of wide reaching consequence: the encounter between Francisco Pizarro, accompanied by friar Valverde and an indigenous translator, and the Inca emperor Atahualpa, in the Peruvian city of Cajamarca to the north of Cuzco, on November $16^{\text {th }}, 1532$. In a second step, this analysis will then focus on the subsequent cultural transfer of representations of a crucial event in the Spanish 'conquest' of South America to other cultural areas and historical contexts, especially France and Britainduring the eighteenth century. The cultural transfer of the representations of the event of November $16^{\text {th }}, 1532$ from 16 th century Spain to $18^{\text {th }}$-century Europe signified not merely the transmission and the more or less faithful reproduction and also the translation of $16^{\text {th }}$-century testimonies and texts in other languages, but also, and predominantly, their critical commentary and reinterpretation outside of Spain.

\section{ATAHUALPA, VALVERDE AND PIZARRO - MISUNDERSTANDINGS AND VIOLENCE IN AN INTERCULTURAL DIALOGUE}

The encounter between, on the one side, the 54 year-old Francisco Pizarro, the leader of the Spanish conquerors of Peru, and Pizarro's chaplain Vicente de Valverde, a Dominican friar and later on Bishop of Cuzco, with, on the other side, the King of the Incas, the approximately 30 year-old Atahualpa in the Peruvian town of Cajamarca, on november 16th, 1532 was undoubetly one of the most important, and far-reaching episodes of the Conquista. It was in this moment that, after supposedly having thrown to the earth the Holy Bible, the Inca King was captured by the Spaniards. Constituting a pretext for Pizarro and his fellowmen to seize Atahualpa and to remove him from his throne, this scene of conflictual interaction and dialogue was also, along with the encounter between Moctezuma and Cortez in 1523, one of the decisive turning-points of the Conquista of South America. It was preceeded by a brief encounter between Hernando Pizarro, the younger brother of Francisco Pizarro (called "governador" in Jangada | ano 9, nr. 17, jan/jun, 2021 | ISSN 2317-4722 


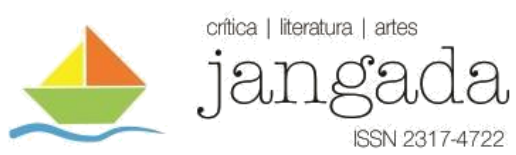

the contemporary sources), accompanied by Hernando de Soto and the interpreter Felipillo, with Atahualpa and members of his court on November $15^{\text {th }} 1532$. This preliminary encounter aimed to determine the time, the place and the protocol of the encounter of the Inca with the Spanish leader. The wording of this preliminary intercultural encounter, which undoubtedly determined their mutual expectations, is not transmitted in any of the contemporary accounts, but only summarized in some of them in a very concise yet imprecise way. ${ }^{6}$

The decisive meeting between Francisco de Pizarro and Atahualpa took place in the temporary, relatively modest residence of the Inca King in the center of Cajamarca where he stayed with his wives and a small part of his court. A previously planned exchange between the Spanish leaders and the Inca King on the previous day, November $15^{\text {th }}$, had been postponed as the Spaniards were told that Atahualpa was unable to receive them, because he was engaged a ritual fast that day. ${ }^{7}$ According to Spanish chronicles of the time, the encounter began with the Inca reception of Francisco Pizarro (who was accompanied by his brother Hernando and two dozens of Spanish warriors) and friar Valverde, who had brought along with him from Panama a large wooden cross strapped to his mule. ${ }^{8}$ After some introductory words from Francisco Pizarro, who respectfully greeted the Inca King, Valverde explained in a relatively long discourse translated by a named Felippo (or Felipillo, sometimes also written Philipillo), the reasons for the arrival of the Spaniards in Peru. In a complex argumentation, which confronted the translator with huge, even unsurmountable difficulties, Friar Valverde exposed the mysterious doctrine of the Trinity, the subsequent mission of the Apostle Peter and his successor, the Pope at Rome, to hold authority over all of the powers and potentials of the earth. According to the explanations of Valverde, the Pope had commissioned the Spanish emperor to convert all natives of the western hemisphere. Valverde's speech aimed at convincing Atahualpa to adopt the Christian religion, to renounce his own religion and to pay tribute to the Spanish Emperor, a request that Atahualpa apparently did not really understand. Apparently,

\footnotetext{
${ }^{6}$ See for example the account in TRUJILLO, Diego de. Una relación inedita de la conquista. La Crónica de Diego de Trujillo. Lima; Miraflores: Ed. by Raúl Porras Barrenechea. Lima, 1970, p. 52 (Embajada de Soto y Hernando). ${ }^{7}$ See on the historical events the following representations by historians and specialists of the Conquista, which don't take sufficiently into account, in their appently 'objective discourse', the ambivalences, contradictions and silences of the sources: BERTRAND, Carmen; GRUZINSKI, Serge. Histoire du nouveau monde. De la découverte à la conquête, une expérience européenne, 1492-1550. Paris: Fayard, 1991, p. 461-474; STERLING, Stuart. Pizarro, Conqueror of the Inca. Phoenix Mill: Sutton Publishing, 2005, p. 37-40 ; LAVALLÉ, Bernard. Francisco Pizarro, conquistador de l'extrême. Paris: Payot, 2004, p. 129-147.

${ }^{8}$ See on these details Sterling, Pizarro, p. 37 who refers to contemporary Spanish chronicles.
}

Jangada| ano 9, nr. 17, jan/jun, 2021 | ISSN 2317-4722

246 |Pági in a 
before proceeding with further negociations and agreements, Atahualpa first firmly demanded that the Spaniards restitute all the goods and treasures they had taken since their arrival in Peru. Then he affirmed that he would also consider the Spanish King as a great ruler, comparable to the dignity of the Inca Kings, but that this position could not legitimate any submission to his power. The Inca King finally explained that he venerated, like his ancestors, only the Sun and the Moon and wanted to know the source of the ideas that the Spanish priest had presented to him. Valverde seems to have told him that it came from the Bible. He handed the book over to Atahualpa who manipulated it, opened it, leafed through the pages, attempted to listen to it, and then let it fall to the ground affirming that he could not hear anything. According to the Indian interpreter serving the Spanish, Felipillo, Atahualpa reportedly said "Let none of them escape!", to which the Indians responded "Inca, let it be so." Anticipating further actions by the Inca King, Pizarro captured him on his royal Sedan chair. Atahualpa was then violently brought away with the help of Pizarro's mounted warriors who killed a great number of the members of Atahualpa's court who were overwhelmed by both the surprising rapidity and the extreme brutality of Pizarro's reaction. ${ }^{10}$ This reaction had been facilitated by the fact that Atahualpa "had not been accompanied by his squadrons of warriors when he had entered the town [of Cajamarca]", intending apparently "to demonstrate to both the Spaniards and his own people his sovereignity and courage $[\ldots] . " 11$

The testimony of Francisco Hillaquita Atahualpa, Atahualpa's son, suggests another reason for the fatal dynamic of misunderstanding in Cajamarca on November $16^{\text {th }} 1532$ that ultimately led to the death of his father. He was one of the two orphaned children of the Inca King who, after the death of their father, were abandoned in the Santo Domingo monastery in Cuzco, and then brought to Quito in Ecuador, by Almagro, one of Pizarro's closest companions, where they earned their living as servants under the care of Dominican monks. Perhaps under the pressure of his Spanish tutors, he attributed the main responsibility not to the character of the Spanish conquistador, but to the intrigues of his translator, Felipillo, "who was said to have overheard Atahualpha ordering an attack on the town."12 Atahualpa's son affirmed this in a testimony handed down in a manuscript conserved in the General Archives of Sevilla and

\footnotetext{
${ }^{9}$ Ibid., p. 39

${ }^{10}$ See on the historical details of this action, based on contemporary sources and testimonies ibid. p. 39-40.

${ }^{11}$ Ibid., p. 41.

${ }^{12}$ Ibid., p. 54.

Jangada | ano 9, nr. 17, jan/jun, 2021 | ISSN 2317-4722 
discovered only in 1934: "The truth is, that they killed Atahualpa because of the lies of the tongue of Don Felipe [Felipillo], who had invented such lies because he had slept with one of Atahualpa's wives and he feared for his life."13 Although unconfirmed by other testimonies and seemingly lacking in plausability, this claim nonetheless reflects the importance of the figure of the interpreter as a cultural broker ${ }^{14}$ and as an intercultural mediator (or "mediating agent"15) suddenly possessed, in specific historical situations, with considerable power. The role and the communication strategies of 'cultural brokers' could be motivated by personal interests, but also by political strategies, as it was the case with the Indian spy that Atahualpa placed among the servants of the Spaniards at their arrival in the Peruvian highlands in $1532 .{ }^{16}$

Taking advantage of dynastic rivalries inside of the Inca Empire between Atahualpa and his brother Huáscar, who were struggling for the succession of their father Inca Huayna Capac who had died in 1528, but also aware of the fact that Atahualpa was venerated as "Sun king", an untouchable divinity, the Spaniards kept him from mid november 1532 for one year in relatively confortable captivity where he was surrounded by his wives and a part of his court. This situation allowed Pizarro to increase constantly his demands for the payment of a considerable ransom in gold and to gain time until the arrival of important military reinforcements coming from Panama under the command of Diego Almagro. Having rendered the ransom, Pizarro broke his promise to liberate Atahualpa. Instead of sending him as a royal prisoner to Spain, as Almagro had proposed, Francisco Pizarro decided to execute him. As Atahualpa had apparently agreed to be baptised by Friar Valverde, he was not burnt alive, but strangled on December 5, 1533, more than one year after his first and decisive encounter with the Spaniards in Cajamarca. Here again, due to ambivalent translations, voluntary misinterpretations and diverging transmissions, different versions of his final testament make it unclear what really happened on the last day of Atahualpa's life:

\footnotetext{
${ }^{13}$ Archivio de las Indias, Sevilla, Manuscript Información de Francisco Atahualpa. Quoted in: STERLING, Stuart. Pizarro..., p. 54. See also on this point: BERTRAND, Carmen. Un Inca platonicien. Garcilaso de la Vega 15391616. Paris : Fayard, 2006, p. 68 : «Ainsi l'interprète Felipillo, bousculant tous les interdits, se prend de passion pour une des épouses de Atahaualpa. Contrarié dans son désir par l'Inca, il se venge en traduisant de travers ses propos. »

${ }^{14}$ See on this notion Antje Dietze: Cultural Brokers and Mediators. In: MIDDELL, Matthias. (ed.): The Routledge Handbook of Transregional Studies. London/New York, Routledge, 2019, p. 494-502.

${ }^{15}$ See on this point more generally: QUEIJA/ARES, Berta; GRUZINSKI, Serge. (eds.): Entre dos mundos. Sevilla: Fronteras Culturales y Agentes Mediadores, 1997.

${ }^{16}$ Testimony by Cieza de León, mentioned by Lavallé, Pizarro, p. 112.
}

Jangada | ano 9, nr. 17, jan/jun, 2021 | ISSN 2317-4722 


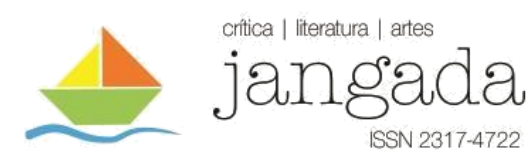

A witness recorded that he continually repeated in quéchua: "Why are they going to kill me? What have I or my sons or my wives ever done to them?" He was then addressed through an interpreter by the Friar Valverde and urged to accept baptism, but he made no reply until a Cañari tribesman whom Pizarro had appointed his executioner approached him. It was then, the horseman Lucas Martínet recorded, that he began to cry out, entreating Valverde, as if he were agreeing with what had been demanded of him, and Valverde baptised him, giving him Pizarro's name of Francisco, and telling him that because of his repentance he would not be burnt alive as had been decreed. He once more began to cry out, gesturing with his hands and indicating the height of his children whom he said were very young, pleading Valverde to recommend their safety to Pizarro. ${ }^{17}$

The Spanish chronicles of the 16th century represent the official version of the conquest of Peru and, in particular, of the intercultural encounter between Pizarro and Atahualpa on November $16^{\text {th }}, 1532$. The first testimonies that were published are those of some of Pizarro's companions who returned, for different reasons, to Spain soon after the events: the Conquista de Peru, llamada la Nueva Castilla by Cristóbal de Mena, published in 1534, which was one of the very few chronicles criticizing Pizarro. This very early account by de Mena, who had also been present at Atahualpa's subsequent execution in December 1533, was followed by the Verdadera relación de la conquista del Péru by Francisco Lópéz de Jerez, Pizarro's secretary, who offered a polemic refutation of de Mena's testimony. These first accounts, and in particular López de Jerez' apologetical report, constituted the basis for the first official historiographical publications on the conquest of Peru in the 1540s and 1550s. In Pedro de Cieza de León's Descubrimiento y Conquista del Péru (The Discovery and Conquest of Peru) Pizarro, Atahualpa and Valverde appear as the only main protagonists present during the events of November 16th, 1532, the interpreter Philipillo playing an apparently both efficient and marginal role. The verbal interactions are represented in indirect speech. The narrator appears as omniscient and capable of rendering the thoughts of Atahualpa:

\footnotetext{
${ }^{17}$ Ibid, p. 56. The first quotation comes from Pedro Cieza de Léon, Descubrimiento y Conquista del Péru (1564, first published in an Italian translation), the second one from the testimony of Atahualpa's son Francisco, conserved as a manuscript in the Archivos General de las Indias in Sevilla.
}

Jangada| ano 9, nr. 17, jan/jun, 2021 | ISSN 2317-4722 249 |P á g in a 


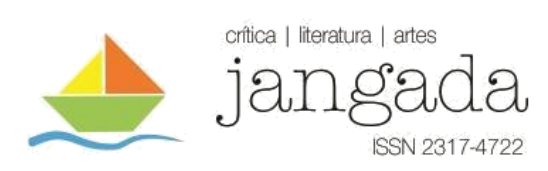

The friar took along Felipillo so that his case would be understood by Atahualpa. When he reached him, he told him what has been said and that he was a priest of God who preached his law and strove whatever possible for peace rather than war because that pleased God very much. While saying this, he held his breviary in his hands. Atahualpa listened to this as something of a mockery. Through the interpreter he understood everything very well. He asked Friar Valverde for the breviary. He placed it in his hands, somewhat disconcerted from finding himself among such people. Atahualpa looked at that and looked at it again, and he leafed through it once or twice. Annoyed with so many pages, he flung it into the air without knowing what it was because he had not understood it, they should have told him in another way, but the friars never preach around here, except where there is no danger or raised lances. And looking at Friar Vicente and Fellipillo, (Atahualpa) said to tell Pizarro that he would not move from the place where he was until they return and restitute to him all the gold, silver, stones, cloth, Indian men and women, and everything else they had stolen. With this answer, having collected the breviary, the skirts flying high, (the friar) rushed back to Pizarro, telling him that the tyrant Atahualpa was like a wounded dog and that they should attack him. ${ }^{18}$

Augustín de Zarate, who is considered as the most reliable Spanish historiographer of the time, also uses an indirect narrative style. In his book Historia del descubrimiento y conquista del Perú (History of the Discovery and Conquest of Peru), first published in 1555, he quotes the dialogues in a very fragmentary way while giving prominence to the speech of Friar Valverde who legitimitated the conquest and asked the Inca King to submit himself to the authority of the Spanish king. The decisive scene after the speech where Atahualpa let the Bible fall to the earth is decribed in Zárate's work as follows:

He asked the bishop how he could know that all he said was the truth and how he could prove such statements.

\footnotetext{
${ }^{18}$ CIEZA DE LEÓN, Pedro. The Discovery and Conquest of Peru. Chronicles of the New World Encounter. Edited and Translated by Alexandra Parma Cook and Noble David Cook. Durham/London: Duke University Press, 1998, p. 211-212 (chap. XLV: «About how Atahualpa entered the plaza where the Christians were, and how he was seized and many of his people were killed and wounded. »)
}

Jangada | ano 9, nr. 17, jan/jun, 2021 | ISSN 2317-4722 


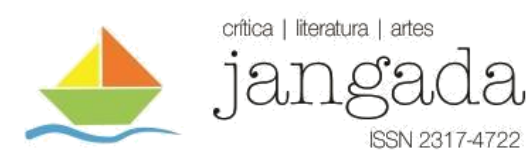

The bishop said that it was written in this book, which was God's scripture. And Atahuallpa asked him for the Bible or breviary he held in his hand. The bishop gave it to him, and Atahualpa turned over the leaves from end to end, saying that it said nothing to him. In fact, it did not speak at all. And he threw it to the ground.

Then the bishop turned towards the Spaniards and cried ,At them! At them! ${ }^{19}$

The following sequence leading to the capture of Atahualpa (called Atabaliba by Zárate) is described by Zarate as a legitimate battle where the Spaniards turned out dominant not because of their number, but because of their courage, their determination, their self control and the fact that Francisco Pizarro who, although injured in the hand during the fight, had perfectly unterstood the crucial importance of the capture of the Inca King. The same episode is related, in a quite similar way, but more explicitly, by the first extensive history of the Spanish conquest of South America, the Historia General de las Indias written by Francisco López de Gómara and published in $1552 .{ }^{20}$ This account was later to constitute a reference work for the historiography of Latin America until the 18th century. López de Gómara used the same largely indirect style of narration as Zárate and Cieza de León and gave a very similar version of the event. But he attributed to Pizarro a more important role in the action. And he extended the short sentence cried out by friar Valverde after the alleged blashemy of Atahualpa who was supposed to have thrown the Holy Bible to the earth: "At them! At them" of the earlier transmission became the more explicit statement: "Los evangelios en tierra; venganza, cristianos; a ellos, a ellos, que no quieren nuestra amistad ni nuestra ley." (The Holy Bible down to earth! Vengeance, Christians; At them, at them, because they want neither our friendship nor our law).

This crucial episode of the conquest of Peru was also one of the central passages of the Commentarios Reales by Garcilaso de la Vega, a mestizo of royal Inca descent who had attended the Spanish schools, but who remained profoundly attached to the values and customs of the Inca culture, and who thus represented one of the first major intellectual mediators (or "brokers") in colonial South America. The encounter between Pizarro, Valverde and Atahualpa

\footnotetext{
${ }^{19}$ ZÁRATE, Augustín de. The Discovery and Conquest of Peru. Translated and with an Introduction by J.M. Cohen. London: Penguin Books, 1968, p. 105.

${ }^{20}$ LÓPEZ DE GÓMORA, Francisco. Historia General de las Indias y Vida de Hernán Cortes (1552). Prólogo y Cronología de Jorge Gurria Lacroix. Venezuela: Biblioteca Ayacucho, 1979, chap. CXIII « Prisón de Atabaliba », p. 169-172, here p. 172. Gomára uses the name of Atabaliba for Atahualpa.
}

Jangada| ano 9, nr. 17, jan/jun, 2021 | ISSN 2317-4722 251 |P á g i n a 
is introduced and commented in Book I, chapter XXV, of the Commentarios Reales (first published in $1609^{21}$ ) as follows:

But the truth of all was this, Friar Valverde startled at a sudden out-cry of the Indians, arose up on a sudden from the seat on which he sate, discoursing with the King; and running in haste, his Book, and the Cross which he held in his hand, fell on the ground; and then catching them up again, he ran with speed, crying to his Companions, that they should offer no hurt to the Indians, for that Atahualpa was kind and well affected towards them, and that he observed by his Answers, and demands his good intentions, to satisfie them in all matters according to his capacity; but the noise and out-cry of the people was such, that the voice of the Friar was not heard among them. And here is to be noted, that it is not true what some Historians report of Atahualpa, that he should say, "You believe that Christ is God, and that he died: I adore the Sun and the Moon, which are immortal: And who taught you, that your God created the Heaven and the Earth?" To which Valverde made answer, "This Book has taught it to us": Then the King took it in his hand, and opening the Leaves, laid it to his Ear; and not hearing it speak to him, he threw it upon the ground. Upon which, they say, that the Friar starting up, ran to his Companions, crying out, that the Gospel was despised, and trampled under foot; Justice and Revenge upon those who contemn our Law, and refuse our Friendship. $^{22}$

This event about which Garcilaso de la Vega gives different versions without ultimately indicating which one could be considered the closest to historical truth, concluded with the capture of Atahualpa, the massacre of more than 5,000 Indians who had initially been instructed by Atahualpa not to use violence and weapons against the Spaniards, and finally with the downfall of the Inca Empire. Garcilaso's discourse closely follows the historical testimonies

\footnotetext{
${ }^{21}$ VEGA, Inca Garcilaso de la. Primer aparte de los Commentarios reales que tratan de los Yncas, reyes que fieron del Perú, de su idolatría, leyes y gobierno en paz y en guerra, de sus vidas y conquistas y de todo lo que fue aquel Imperio y su república antes que los españoles passaran a él. Lisboa: Pedro Crasbeck, 1609.

${ }^{22}$ VEGA, Inca Garcilaso de la. The Royal Commentaries of Peru, in two parts. First translation London, by Paul Ricaut, 1708. Edition quoted here: London, by Miles Flesher, for Christopher Wilkinson, 1788, vol. II, chap. XXV («Of the great tumult and disturbance which happened between the Indians and the Spaniards»), p. 456-457.
} 
but at the same time remains very critical of them. With regard to the quoted scene, he introduces the episode carefully in paying a particular attention to all forms of direct speech and of dialogues in the sources and in examining the complex process of translation between the Spaniards and the Incas. Garcilaso was, in fact, the only historian of the Conquista to pay consistent attention to the cultural dimensions of translation in intercultural communication. $\mathrm{He}$ underlines that the translator was incompetent and completely incapable of meeting the challenge of the situation:

This was all the Education and Learning which our first Interpreter had in Peru, and accordingly the translations he made out of Spanish were all imperfect, and of contrary sense; not that he made mistakes voluntarily from malice, but from ignorance, speaking, like a Parrot, things that he did not understand. [...]. We must add, that the interpretation he made of the Friar's Sermon, served rather to obscure than elucidate his sense. ${ }^{23}$

Garcilaso observes, for instance, that Christian concepts had to be translated by the translator from Spanish to Quechua and then to Aymara, in a process where they lost almost all of their sense : ,[...] when he came to explicate the Generation of Mankind, and original Sin by Adam's fall; that instead of saying , That all the World sinned in Adam', he would say, ,That all the World heaped their sins upon Adam' “24 The translator rendered the Christian conception that God is both Trinity and Unity with the phrasing "God, three and one makes four, which was not incomprehensible to the Peruvians. These problems of translation inherent to the event of the encounter between Atahualpa, Valverde and Pizarro were illustrated, according to Garcilaso, by the tradition of the quipus, or annual records in knots, kept at Cajamarca, where the event occurred: „in the Peruvian language they have no other way to express the Trinity, the Holy Ghost, Faith, Grace, the Church, the Sacrements, and other Words of the Mysteries; for which reason the Spaniards, who study that language in our times, and endeavour to express

\footnotetext{
${ }^{23}$ Ibid, chap. XXIII ( $«$ Of the Difficulty there was to interpret the sense and meaning of this Speech of Friar Vicente de Valverde »), p. 452.

${ }^{24}$ Ibid, p. 453.

Jangada | ano 9, nr. 17, jan/jun, 2021 | ISSN 2317-4722

253 | Pág i n a
} 


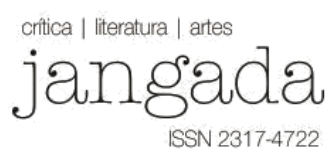

their mystical Notions, are forced to coin new words most accomodated to the reason of this people, and to the manner of expressions of the most intelligent Indians [...]."25

\section{ENLIGHTENED APPROPRIATIONS AND RE-INTERPRETATIONS}

The Enlightenment appropriation and reinterpretation of this central episode of the conquest of America is caracterized by a radical reversal of the discourse of legimation found in the texts of Spanish historians like Augustín Zárate or López de Gómara. The Enlightenment understanding of the Leyenda negra ('Black Legend') -- introduced, notably by Voltaire in the Essai sur les mœurs (1756), the Abbé Prévost in the Histoire générale des Voyages (1749-49), by Guillaume-Thomas Raynal in the Histoire des deux Indes ( $1^{\text {st }}$ edition 1770), and by William Robertson in his influential History of America (1777) -- was largely based on the narratives of Spanish historians and chroniclers, but had its sense change completely in the commentary. In his best-selling historical narrative Les Incas (1777), Jean-François Marmontel also presented a very critical view of the Spanish Conquest of South America and of the conquistadores. His narrative was based on Spanish colonial sources, but also on the Abbé Prévost's Histoire Générale des voyages, the Commentarios reales of the Inca Garcilaso de la Vega and especially on the Historia del mondo nuevo (Venezia, 1565, enlarged edition 1572) written by the Italian merchant and adventurer Girolamo Benzoni (1519-1572), a native of Milan who had spent almost 15 years in the New World travelling also to Peru, between 1541 and 1566 when he along with other foreign merchants was expelled from the Spanish colonies. ${ }^{26}$

Benzoni's Historia del Nuevo Mundo, published originally in Venice in Italian, was based on Spanish chronicles and historiographical writings on the Conquista, notably those written by Oviedo y Valdés, López de Gómara, Cieza de Léon and Bartolomé de Las Casas ${ }^{27}$, but also on personal observations and inquiries. Due to the numerous editions (in the whole 31

\footnotetext{
${ }^{25}$ Ibid., p. 452.

${ }^{26}$ See on Marmontel's sources: Pierino Gallo: Introduction. In: MARMONTEL, Jean-François. Les Incas, ou la destruction de l'Empire du Pérou. Texte établi et présenté par Pierino Gallo. Paris : Société des Textes Français et Modernes, 2016, p. 7-66, ici p. 39-58; Delhoume-Sanciaud, Les Incas, vol. I, p. 319-576.

${ }^{27}$ Ferdinand Anders : Girolamo Benzoni. Leben und Werk. In : BENZONI, Girolamo. Historia del Mondo Nuovo. Einleitung Ferdinand Anders. Zweite ergänzte und erweiterte Ausgabe. Graz, Akademische Druck-und Verlagsanstalt, 1969 (Frühe Reisen und Seefahrten in Originalberichten vol. 8), LI, 181 p., here p. V-LI, p. XI on his printed sources.
}

Jangada| ano 9, nr. 17, jan/jun, 2021 | ISSN 2317-4722 254 |P á g in a 
in the $16^{\text {th }}-18^{\text {th }}$ centuries $^{28}$ ) of this account and its translations into five foreign languages beginning in 1578 (Latin, German, French, Dutch and English ${ }^{29}$ ), Benzoni’s Historia became the most influential text across Europe for the diffusion of the Spanish 'Black legend' , denouncing the violence and the thirst for gold of the conquistadores and the complicity of the clergymen. The book III of his Historia del Nuovo Mundo gives a long account of the encounter between Pizarro, Valverde and Atahualpa (who is called "Attabaliba") in Cajamarca on November $16^{\text {th }}$, 1532. Benzoni first presents a brief account of the preliminary encounter between Atahualpa and Pizarro's brother Fernando (or Hernando), who was well received by the Inca and who reported to Francisco Pizarro the "wonderful riches and great display of the king, as also his royal will, that he would not suffer any bearded men in his kingdom." 30 Without mentioning Francisco Pizarro's brief introductory speech to Atahualpa which formed, following other testimonies, the initial part of the encounter, Benzoni presented in a detailed manner the speech given by Friar Valverde, which was also translated by a Peruvian interpreter ("interprete"). With his cross and his breviary in his hand, he gave Atahualpa to understand, "by means of the interpreter", that:

He came to his excellency commissioned by his sacred majesty the emperor, with the authority of the Roman pontiff, celestial vicar of our Saviour, who had given him the unknown countries, so that he might send there worthy persons to preach and to publish his most holy name, doing away with their false and diabolical errors: thus saying he shewed him the law of God, who created all out of nothing. ${ }^{31}$

After having then related the destiny of Adam and Eve, the life of Jesus Christ, how he decended from heaven and how he died on the cross, the resurrection of the dead and the life of Peter his first vicar, Friar Valverde explained, according to Benzoni, to the Inca King the

\footnotetext{
${ }^{28}$ See the list of the editions in TOSI, Carlo Angelo. Un Milanese nel nuovo mundo. Le Indie di Girolamo Benzoni. Zermeghedo: Edizioni Saecula, 2017, p. 97.

${ }^{29}$ During the 16th and 17th centuries were only published extracts in English translation. The first complete translation in English was published in 1872 in London. See the different editions and translations in Anders, Girolamo Benzoni, p. XXXI-XXXVIII.

${ }^{30}$ BENZONI, Girolamo. History of the New World, shewing his travels to America, from A.D. 1541 to 1556, with some particulars on the island of Canary. Now first translated, and edited by Rear-Admiral W.H. Smyth. London: Printed for the Haklyut Society, 1857 (Works issued by the Haklyut Society), p. 178.

${ }^{31}$ Ibid, p. 178.
}

Jangada | ano 9, nr. 17, jan/jun, 2021 | ISSN 2317-4722 


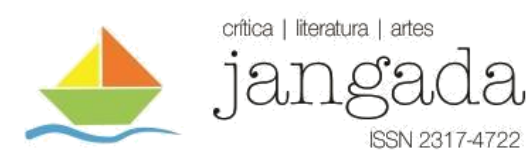

authority of the pontiffs his successors and the authority of the monarch of Spain, "monarch of the world." ${ }^{32}$ Valverde concluded his speech, to which Atahualpa listened with attention, but also with great surprise, having only grasped a small part of its translated version, by showing "the king that it was duty to become a friend and tributary, submitting to the divine law and Christian religion, abandoning the false gods." 33 He had then said literally, in his final words, and according to Benzoni: "and if you do not accede to this, war will compel you to it".34 Benzoni added to this passage the following ironic commentary in the margins: "Marvellous deal for a monk who wanted to spread the Gospel by force." ${ }^{35}$ Atahualpa's following reaction to Valverde's speech is also given by Benzoni in a summary and not through literal quotations:

When the king had heard all this, he said that he would live in friendship with the monarch of the world; but it did not seem, to him, incumbent on a free king to pay tribute to a person whom he had never seen; and that the pontiff must be a great fool, giving away so liberally the property of others. As to the religion, he would on no account abandon his one; for if they believed in Christ who died on the cross, he believed in the sun, who never died. ${ }^{36}$

Responding to Atahualpa's question regarding the claim that the "God of the Christians" 37 had made the earth from nothing, as he had explained, and that Jesus-Christ had died on the cross, Valverde handed him the Bible, saying that this book provided all the information. Having put the book to his ears and having manipulated it in various ways, Atahualpa finally said that "this says nothing to me" and threw the Bible to the earth. Valverde's words "Vengeance, vengeance, Christians. For the gospels are despised and thrown on the ground! and thrown them to earth. Kill these $\operatorname{dog} s$ who despise the law of God!" 38 are explicitly

\footnotetext{
${ }^{32}$ Ibid, p. 178.

${ }^{33}$ Ibid, p. 178-179.

${ }^{34}$ Ibid, p. 179. The English translator quotes in a footnote in page 179 this passage in Italian ("e non le farete, la guerra vi sforzera à questo") and comments as follows, in giving a second, more literate translation of Valverde's words: "In other words, this ranting Dominican said to the unoffending sovereign of another people - „Do as you like, but if you don't we'll make you." (Transl.).

35 BENZONI, Girolamo. Historia del Mondo Nuovo. Venetia: Pietro \& Francesco Tini, 1572, Lib. III, p. 121-124 (Reprinted in Graz, Akademische Druck- und Verlagsanstalt, 1969, see footnote 27); in the French edition, p. 563. This commentary is not translated in the English version.

${ }^{36}$ Ibid, p. 179.

${ }^{37}$ Ibid, p. 179 .

${ }^{38}$ Ibid, p. 179. This sentence is also put in quotation marks, indicating direct speech in the original text.
} Jangada | ano 9, nr. 17, jan/jun, 2021 | ISSN 2317-4722 256 |P á g i n a 


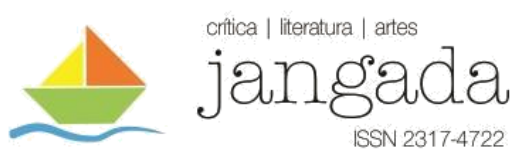

mentioned by Benzoni and put into quotations marks in order to underline their veracity. In Benzoni's view, the translator bore no major responsibility for the tragic events which subsequently took place in Cajamarca, in contrast to the violent and bloodthirsty Spanish conquistadores and their accompanying clergymen who abandoned all norms of morality, respect and moderation in their unlimited thirst for gold and silver. According to Benzoni, after Valverde' cry for vengeance,

Francisco Pizarro having unfurled his flags, gave the order for battle. Thus the first guns were fired; and immediately on this alarm the horses followed, with bells around their necks and their legs, making a great noise, added to the crashing of the trumpets and drums. Laying hands on their arms they attacked the Indians, who, stupified by so much novelty, by so much ferocious animals, and by the sharpness of the swords, began to clear away and fly in utter disorder. Owing to their very great multitude they trod each other down, and were suffocated on the ground; so that the lances and the swords made the most horrid havoc of them in their attemps to escape: happy he who could get away to save his life. ${ }^{39}$

Marmontel's narrative description of this scene in his romance Les Incas (1777) followed the Italian original of the Historia del nuevo mundo ${ }^{40}$ quite closely, but differs from the wording of the French translation of the text. Integrating two other main sources -- the French translations of Augustín Zárate's ${ }^{41}$ Historia del descubrimiento y conquista del Peru (1555) and of Garcilaso de la Vega's Histoire des guerres civiles des Espagnols dans les Indes ${ }^{42}$ -- it seems likely that Marmontel's text represents a new or a revised translation of the Italian original text of Benzoni's account, which is present in one sentence and left in Italian without translation: the sentence reads "Uccidete questi cani che dispreggiano la legge di dio," ${ }^{43}$ which

\footnotetext{
${ }^{39}$ Ibid, p. 179-180.

${ }^{40}$ See on this point: DELHOUME-SANCIAUD, Monique. «Les Incas ou la destruction de l'Empire du Pérou » de Jean-François Marmontel. Paris: Honoré Champion, 2017, vol. II, p. 1125-1132.

${ }^{41}$ ZARATE, Augustín de. Historia dle descubrimiento y conquista del Peru. Anvers : Matin Nucio, 1555. French translation: ZARATE, Augustín de. Histoire de la découverte et de la conquête du Pérou. Traduite de l'espagnol. Paris : Compagnie des Libraires, 1774, 2 vol., here vol. I, chap. V, p. 107-115.

${ }^{42}$ Vol. I, liv. I, chap. XVIII-XXVII.

${ }^{43}$ MARMONTEL, Jean-François de. Les Incas ou la destruction de l'empire du Pérou. Liège, Bassompierre, 1777, vol. II, ch. XLIX, 218-230,; see for the original Italian passage: BENZONI, Girolano. Historia del Mondo Nuovo, p. 123. The passage is identical in the first edition, Venetia : Pietro e Francisco Tini, fratelli, 1572, p. 123.
}

Jangada| ano 9, nr. 17, jan/jun, 2021 | ISSN 2317-4722 257 |P á g i n a 


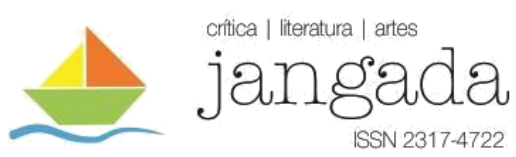

can be translated as "Kill these mecreant dogs who trample the law of God". It may be presumed that Marmontel left in Italian Valverde's very strong sentence, which reveals both the arrogance and the brutality of the representative of the Catholic Church during the encounter at Cajamarca, in order to avoid the censorship of the Sorbonne. ${ }^{44}$ In his 1777 historical narrative Les Incas, Marmontel thus transformed the dialogue between Pizarro (called "héros Castillan"45) and Atahualpa into a confrontation between two very different conceptions of power and sovereignity which were placed by the author on the same level. This dialogue is described as initially polite and respectful, showing the two interlocutors as representatives of two very different, but equally sophisticated civilizations, but also of universal values. But Valverde and Pizarro very quickly reveal, according Marmontel's representation, the fanatism and brutality of their actual attitudes, defending values radically opposed both to the Christian religion and to the Enlightenment, whereas Atahualpa incarnates Reason ("Raison") and Humanity ("Humanité"). ${ }^{46}$ Pizarro seems profoundly convinced of his own superiority and of the superiority of the Spanish civilization, whereas the Inca Atahualpa seems willing to listen to the Other and to learn from him. His closing remarks to Pizarro are as follows: "Come and instruct us, illuminate us with your reason, enrich us with your wisdom; and be assured of finding us docile and grateful." 47 According to Marmontel the encounter "went smoothly on, till the hypocritical and furious Valverde required to speak in his turn." ${ }^{48}$ The speech by Valverde is summed up and simultaneously commented upon in a very negative way by Marmontel. ${ }^{49}$ It is then followed by a brief dialogue between Atahualpa and Valverde who explains the role of the Bible to the Inca king "in an arrogant tone." ${ }^{50}$ Atahualpa's reply and his

\footnotetext{
${ }^{44}$ See also on this point: DELHOUME-SANCIAUD, Monique. «Les Incas ou la destruction de l'Empire du Pérou » de Jean-François Marmontel. Paris: Honoré Champion, 2017, vol. II, p. 1132.

${ }^{45}$ MARMONTEL, Jean-François. Les Incas, ou la destruction de l'Empire du Pérou. Paris : Lacombe, 1777, 2 vols., here vol. II, p. 221. English translation: The Incas, or The Destruction of the Empire of Peru. Dublin: Messrs. Price, Whitestone, 1777, 2 vols.

${ }^{46}$ See also on this point: DELHOUME-SANCIAUD, Monique. "Les Incas ou la destruction de l'Empire du Pérou » de Jean-François Marmontel. Paris: Honoré Champion, 2017, vol. II, p. 1133.

${ }^{47}$ Here quoted after the English translation: MARMONTEL, Jean-François. The Incas, or the Destruction of the Empire of Peru. Dublin: A. Stewart, 1797, 2 vols., here vol. II, p. 236. The passage in French sounds as follows in Marmontel, Incas, vol. II, ch. XLIX, p. 219 : « Traite-nous de même; ou du moins, avant de nous juger, commence à nous connoître, \& ne fais pas retomber sur nous les maux que nous n'avons pas faits. »

${ }^{48}$ Ibid, p. 236.

${ }^{49} \mathrm{Ibid}$, p. 237: "He then imprudently plunding into the profound darkness of our awful mysteries, in the number of which he comprised the authority of a man ordinated by God himself to command Kings, to exercize domination over nations, to dispose of crowns, and all the possessions of sovereigns and subjects, and externinate those who disclaim the plentitude of this power."
}

${ }^{50}$ Ibid, p. 237. 
gesture, which led to the violent reaction of the Spaniards and the massacre of the members of Atahualpa's court and to his imprisonment, largely follows the text of Benzoni, which is explicitly quoted by Marmontel, even if the quoted oral words are slightly different:

The Inca, without emotion, receiving the book, and looking upon it, said: 'Every thing that Pizarro told me, I can conceive, and, without difficulty, believe. But what I hear from you appears unintelligible; and this book is silent, it tells me nothing.' He added, it is said, some offensive expressions concerning the man, who arrogated to himself the right of commanding Kings, and disposing of Empires; and either through contempt or negligence, in returning the book to Valverde, let it fall. This was enough. The fanatical monk transported with rage, ran towards the Spaniards and began to cry out for vengeance in the name of Religion, which this barbarian had trampled under foot. ${ }^{51}$

Without mentioning the presence of the translator, the related problems of translation and the possible misunderstanding and manipulation, Marmontel situates his discourse in the anti-clerical and anti-papal movement of the late Enlightenment. Following Benzoni, he attributes a particuliarly negative role to Valverde, who is caracterized as full of arrogance ("plein d'arrogance"), fiery ("fougueux"), cunning ("fourbe"), fanatic ("fanatique"), hypocritical ("hypocrite") and furious ("transporté de fureur"). According to Marmontel, after the reaction to Valverde's "strange" speech, Atahualpa "dropped" the Bible (meaning that he did not throw it down, as mentioned in other versions of the event), when intending to give it back to Valverde, saying to him that it was silent ("muet"). ${ }^{52}$ Valverde, according to Marmontel's description, was then "carried away by fury" ("transporté de fureur" ${ }^{53}$ ), called for violent revenge and thus deliberately provoked the perfidious imprisonment of the Inca King and the massacre of the nobles surrounding him. Marmontel explicitly emphasizes the moral and intellectual superiority of Atahualpa in comparison with Valverde's character, but also with

\footnotetext{
${ }^{51}$ Ibid, p. 237-238; French original: MARMONTEL, Jean-François. Les Incas, vol. II, ch. XLIX, p. 224.

52 Ibid., p. 224 : «Mais ce que tu me dis, je ne saurois le concevoir ; \& ce livre, muet pour moi, ne m'en instruit pas davantage. »

${ }^{53}$ Ibid., p. 224: «Le prêtre fanatique, transporté de fureur, se tourne vers les Espagnols, \& se met à crier vengeance pour la religion, que ce barbare foule aux pieds. »
}

Jangada| ano 9, nr. 17, jan/jun, 2021 | ISSN 2317-4722

259 | Pá g i n a 
regard to Pizarro and his companions. ${ }^{54}$ Some contemporary critics reacted to Marmontel's very negative view of the Catholic clergy in Les Incas, and especially to the image given by friar Valverde, the future bishop of Cuczo, which was revealed by the events of Cajamarca, in opposing to Valverde the positive role of Las Casas as "Protector of the Indians." 55 Marmontel also introduced into his fictional discourse signs of doubt and ambivalence, for example when he uses the locution "it is said" or when he introduces alternative interpretations of the reactions of the Inca ("contempt or negligence" 56 ).

Guillaume-Thomas Raynal reproduced, in his Histoire... des deux Indes $\left(1^{\text {st }}\right.$ edition in 1770), in a very condensed way, the narrative of Benzoni, taking over friar Valverde's cry of vengeance "Tuez-moi ces chiens, qui foulent aux pieds la loi de Dieu“" ("Kill for me these dogs who trample upon God's Law"), ${ }^{57}$ but also changing some very significant details. Raynal's narrative discourse only mentions Valverde's speech (and not Pizarro's introductory speech) and very briefly Atahualpa's reaction to it; in Raynal's version, Valverde is only carrying with him the Bible ("le bréviaire") and not the Holy Cross. Furthermore, Raynal reinforces the representation of the brutality of the Spanish conquerors, the two clergymen incarnated by Valverde and the military forces by deploying such language as a "furious passion for blood and gold", ${ }^{58}$ in describing the Spaniards as "murderers" ("assassins") and when referring to the events not as a battle, but as a "blood bath" ("carnage") and an infamous slaughter ("infâme boucherie") ${ }^{59}$ followed by a night of drunkeness, dancing and all kinds of sexual excesses ("les Espagnols passèrent la nuit à s'enivrer, à danser, à se livrer à tous les excès de la débauche"). ${ }^{60}$ In contrast to Garcilaso de la Vega whose Commentarios reales also served as the basis for the

\footnotetext{
${ }^{54}$ See also on this point: DELHOUME-SANCIAUD, Monique. « Les Incas ou la destruction de l'Empire du Pérou » de Jean-François Marmontel. Paris: Honoré Champion, 2017, vol. II, p. 1133.

${ }^{55}$ See for example Lettre d'un lecteur du Journal François, et de l'Année Littéraire, à M. Marmontel, Sur les Incas, ou la Destruction de l'Empire du Pérou; avec le Précis Historique de la Vie de Las-Casas, Protecteur des Indiens. A Londres, et se trouve à Paris, Chez les Libraires qui vendent les Nouveautés, 1777, in- $8^{\circ}, 22$ p. BnF ARS $8^{\circ}$ BL.Z.37937.

${ }^{56}$ MRMONTEL, The Incas, p. 237; MARMONTEL, Les Incas, p. 224.

${ }^{57}$ RAYNAL, Guillaume-Thomas. Histoire philosophique et politique des établissemens et du commerce des Espagnols dans les deux Indes. Neuchâtel et Genève : Chez les Libraires Associés, 1783, vol. III, livre 7, chap. V, p. 297. See also the critical edition of Raynal's work : RAYNAL, Guillaume-Thomas Raynal. Histoire philosophique et politique des établissemens et du commerce des Espagnols dans les deux Indes. Édition critique. Sous la direction de Anthony Strugnell, Gianluigi Goggi and Kenta Ohji. Tome II. Livres VI à IX. Sous la direction de Andrew Brown et Hans-Jürgen Lüsebrink. Ferney-Voltaire : Centre International d'Étude du XVIIIe siècle, 2018, p. 128-130 (critical commentary by Susanne Greilich).

${ }^{58}$ Ibid, p. 129: "cette fureur, cette soif de sang que leur inspiroit la vue de l'or".

${ }^{59}$ Ibid, p. 129-130.

${ }^{60} \mathrm{Ibid}$, p. 130.
}

Jangada | ano 9, nr. 17, jan/jun, 2021 | ISSN 2317-4722 


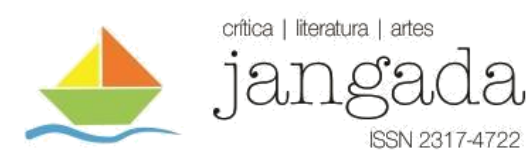

text published on the conquest of the Inca Empire in the Abbé Prévost's Histoire Générale des Voyages $^{61}$, Raynal did not consider the problems of intercultural translation and misunderstanding. Like Marmontel, he strongly opposed the two discourses and the two worldviews - those of Atahualpa on the one side and those of Pizarro and Valverde on the other side - giving a very positive semantic profile to the Inca who appears as a self-confident, proud, fair and wise king, in opposition to the brutal Spanish invadors who are called "Assassins" (killers). The Spanish are painted with the darkest colors, especially friar Vincent Valverde who is even said to have exhorted them to massacre the Indians in using not the edge, but the point of their swords in order to cause deeper injuries. ${ }^{62}$

Finally, in William Robertson's History of America the events at Cajamarca occupy four pages in book VI of the in-octavo-edition of 1778 concerning the conquest of Peru. The encounter between Pizarro and Atahualpa is supposed to have occurred in the absence of historical contingency, but rather as a very precise scheme of ruse and conquest imagined by the Spanish conquistador, and based on personal experience: "From his own observation of American manners during his long service in the New World", we read in book VI that, "as well as from the advantages which Cortes had derived from seizing Montezuma, he knew of what consequence it was to have the Inca in his power, for that he formed a plan as daring as it was perfidious." ${ }^{63}$ Based probably in part on the first edition of Raynal's History of the two Indies published in 1770, Robertson's version largely follows Raynal's narrative, except in two nevertheless quite important points: Robertson is far more moderate in his description of the Spaniards who appear as decided and brutal strategists, but not as bloody and libertine monsters. Friar Vincente is not described as a brutal "killer", but "only" as an "enraged monk". ${ }^{64}$ And the last sentence of his violent cry exhorting the Spaniards to bloody vengeance, which had been added in the Raynal version, was slightly modified by Robertson. Instead of "Kill for me these dogs who trample upon God's Law", Robertson put the more moderate formulation "The word

\footnotetext{
${ }^{61}$ PRÉVOST, Abbé. Histoire générale des voyages, Paris : Didot, 1752, t. 49, LVI, ch. 3, p. 190-191. See on this passage also in DELHOUME-SANCIAUD, Monique. «Les Incas ou la destruction de l'Empire du Pérou »de Jean-François Marmontel. Paris: Honoré Champion, 2017, vol. II, p. 1132-1133.

62 Ibid, p. 298 : «Tant que le carnage dura, Vincent ne cessa d'animer les assassins fatigués de tuer, les exhortant à se servir, non du tranchant, mais de la pointe de leurs épées, pour faire des blessures plus profondes. »

${ }^{63}$ ROBERTSON, William. The History of America. By William Robertson, Principal of the University of Edinburgh, and Historiographer to his Majesty for Scotland. London: Printed for W. Strahan, T. Cardell, J. Balfour, 1777, 2 vols, here vol. II, book VI, p. 173).

${ }^{64}$ Ibid, p. 175.
}

Jangada | ano 9, nr. 17, jan/jun, 2021 | ISSN 2317-4722

261 | Pág i n a 


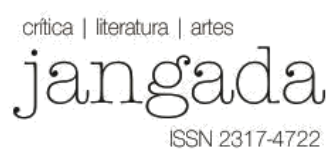

of God is insulted; avenge this profanation on those impious dogs." 65 Robertson pays some attention to the intercultural misunderstandings, following on this point Garcilaso's representation of the episode in describing the effect on the Inca King of Valverde's badly translated speech (which required his submission to both the political power of the King of Spain and the spiritual power of the Pope in Rome) and his subsequent reaction to this demand. The dialogical sequence in Robertson's version, which is followed by the violent cry of Valverde, is largely formulated in indirect speech, interspersed with commentaries of the narrator, but it gives in quotation marks its own version of the decisive sentence pronounced by Atahualpa after having put the Holy Bible to his ear:

This strange harangue, unfolding deep mysteries, and alluding to unknown facts, of which no power of eloquence could have conveyed at once a distinct idea to an American, was so lamely translated by an unskillful interpreter, little acquainted with the idiom of Spanish tongue, and incapable of expressing himself with property in the language of the Inca, that its general tenor was altogether incomprehensible to Atahualpa. Some parts in it, of more obvious meaning, filled him with astonishment and indignation. His reply, however was temperate. He began with observing, that he was lord of the dominions over which he reigned by hereditary succession; and added, that he could not conceive how a foreign priest should pretend to dispose of territories which did not belong to him; that if such a preposterous grant had been made, he, who was the rightful possessor, refused to confirm it; that he had no inclination to renounce to the religious institutions established by his ancestors; nor would he forsake the service of the Sun, the immortal divinity whom he and his people revered, in order to worship the God of the Spaniards, who was subject to death; that with respect to other matters contained in his discourse, as he had never heard of them before, and did not now understand their meaning, he desired to know where he had learned things so extraordinary. "In this book", answered Valverde, reaching out to him his breviary. The Inca opened it eagerly, and turning over the leaves, listed it to his ear. "This", says he, "is silent; it tells me nothing"; and threw it with disdain to the ground. ${ }^{66}$

\footnotetext{
${ }^{65}$ Ibid, p. 175.

${ }^{66}$ Ibid, p. 174-175.

Jangada | ano 9, nr. 17, jan/jun, 2021 | ISSN 2317-4722
} 


\section{THE FUTURE OF THE PAST ${ }^{67}$ - FROM POTENTIAL TO IMAGINED HISTORY}

This focus on one central episode of the colonial history of modern times - the particuliarly violent intercultural encounter between Atahualpa, Valverde and Pizarro in Cajamarca on November 16th, 1532 -- reveals three different discourses inside what we could call the Enlightenment re-reading of colonial discourses. The first discourse, represented notably by Marmontel, Prévost and Voltaire, denounces the barbarism of the conquerors, and especially of the Spanish conquistadores, but also, especially in the case of Marmontel, the hypocrisy and the fanatism of the monks. This discourse with the historical and philosophical positions it implies, is generally defined as Leyenda negra.

The second discourse, illustrated by Raynal and Diderot but also by such German philosophers as Georg Forster, critizes the Spanish conquest of South America and, more generally, all forms of colonial conquest, slavery and violence in favor of forms of conditional history. This discourse suggests a historical evolution that could have occurred if the thirst for gold had not been so strong among the Europeans, especially the Spanish and Portuguese colonizers. Historical consciousness in a conditional mode of expression can be found in Raynal's Histoire des deux Indes, but also in Diderot's Supplément au Voyage de Bougainville, in the numerous passages where representatives of the colonized adress and accuse the European invaders, fundamentally questioning the legitimacy of any conquest or form of colonization. The German anthropologist and writer Georg Forster, in one of his review articles concerning the academic prize competition at Lyon in 1780 on the usefulness of the discovery of America, points out that this ,imagined potential history' should not be an expression of fear and trauma of the past, but used to develop a constructive perspective on the future. ${ }^{68}$

\footnotetext{
${ }^{67}$ This title refers to a book of KOSELLECK, Reinhart. Vergangene Zukunft. Zur Semantik geschichtlicher Zeiten. Frankfurt/Main: Suhrkamp, 2003; English translation : Future's Past : on the Semantics of Historical Times. New York: Columbia University Press, 2004, in adopting some similar, but also quite different perspectives.

${ }^{68}$ Georg Forster : Abbé M. Genty, «L'influence de la découverte de l'Amérique sur le genre humain. » In : FORSTER, Georg. Sämtliche Schriften, Tagebücher, Briefe. Vol. XI : Rezensionen. Bearbeitet von Horst Fiedl. Berlin: Akademie-Verlag, 1977, p. 134-138, here p. 134 : « Die Sphäre des Möglichen scheint sich in unserer Vorstellung immer weit über die Grenzen der Wirklichkeit auszudehnen ; daher findet jeder, wenn er nach seinem Gefühl, seiner Einsicht und Beurteilungsgabe sich eine hypothetische Form der Sittlichkeit entworfen hat, die wirklichen Gegebenheiten nicht nur mit ihr im Widerspruch, sondern er richtet sich auch gern eine neue, ihr angemeßenere, Ordnung der Dinge ein. »
}

Jangada| ano 9, nr. 17, jan/jun, 2021 | ISSN 2317-4722 263 |P á g i n a 


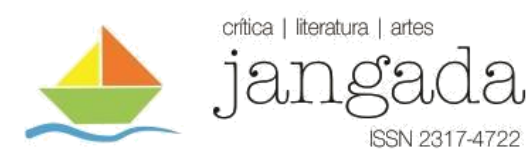

Finally, the third position, represented for example in the 18th-century reception of Garcilaso's Commentarios reales on the conquest of Peru, is based on fundamental doubts concerning all of the sources, and especially those European documents purporting to represent the such oral dimensions of historical interaction as voices, dialogues and speeches. Nobody would ever know, according to this position, what really happened, and what was really said on that decisive November 16th, 1532, in Cajamarca, Peru, between Atahualpa, Valverde, Francisco Pizarro and their translator Felipillo. The modernity of Garcilaso and his eighteenthcentury commentators consists in showing, in a very precise manner, the obvious and farreaching effects of cultural differences, failed translations, misperceptions and intercultural misunderstandings inherent to oral intercultural interaction. His central affirmation is that the encounter in Cajamarca was first a violent communicative event and then also a brutal and bloody military event, which contradicts the official representation, by the Spanish crown, of the voluntary and insightful submission of the Inca King to the Spanish ruler. ${ }^{69}$

From this perspective, Garcilaso de la Vega and the 18th-century reception of his work anticipated the modern and contemporary re-reading and re-interpretation of the Conquista from the point of view of the defeated. The oral and pictural Quechua sources of the events of November 16th, 1532, in Cajamarca, and their indigenous translators and reinterpreters, seem to confirm at least partially Garcilaso's point of view. The only contemporary author of indigenous origin, beside Garcilaso de la Vega, who spent a great part of his life in Spain, was in fact Felipe Huaman Poma de Ayala. He wrote his Primer Buena Corónica y Buen Govierno at the end of the 16th century, but it was first published in 1936. Using oral Quechua sources, the author underlines, as did Inca Garcilaso de la Vega, the importance of intercultural mistranslation and misunderstanding during the events in Cajamarca, where completely different power rituals, value systems and symbolic codes clashed violently. In contrast to most of the contemporary Spanish representations of the event, Poma de Ayala stressed the dignity and majesty ("majestad") of the Inca, his determined, but polite and moderate reactions towards the Spaniards, even with regard to the unknown media of the printed word of the Bible, which he did not "throw down", according to Poma de Ayala, but only "dropped" ("echó el libro de

\footnotetext{
${ }^{69}$ See on this point GRUZINSKI, Serge. Les quatre parties du monde. Histoire d'une mondialisation. Paris : Éditions de La Martinière, 2004, p. 114: «L'image de cette 'soumission joyeuse' est une altération grossière de la réalité historique, conforme à l'idéologie impériale, mais l'interprétation qu'elle propose aux nobles nahuas tempère l'humiliation de la défaite indienne puisqu'elle légitime leur rattachement à la Couronne en la présentant comme la volonté expresse de leurs seigneurs naturels. »
} 
sus manos") ${ }^{70}$. And Valverde's cry is also quoted in a very different - and less hurtful - way by Poma de Ayala than in the Spanish cronicles and the Enlightenment versions, because he is supposed to have said, after Atahulpa's reaction: “Aqué, con estos indios gentiles, son contra nuestra fe!"’1

The oral sources of the defeated -- collected partially by Garcilaso de la Vega and Poma de Ayala, but also present in manuscripts in the Archivos de las Indias in Sevilla -- thereby underline two central issues of the dramatic intercultural dialogue between Atahualpa and the Spanish conquistadores which led to the rapid downfall of the Inca Empire: on the one side, the brutal strategy of the Spaniards, both the clergy and the military forces, using treachery and violence without any scruples; and on the other side, the tremendous cultural differences between the two counterparts, their languages, value systems and rituals, which were not only almost untranslatable, at least for the contemporary actors, but happened to favour, in this case tragically, the Spanish invadors. For Atahualpa and his court, the devious strategy of the Spaniards, combining ruse and surprise, feigned respect and cold blooded thirst for gold and domination, seemed to have been culturally and mentally inconceivable and inimaginable. ${ }^{72}$ The numerous illustrations accompanying the account of Poma de Ayala, a literate Indian of noble descent, significantly do not show the encounter of Cajamarca itself, but its consequences after the death of Atahualpa and the end of the Inca empire in 1533: torture, the rape of Indian women by the Spanish conquerors, and the enslavement of the Peruvians in the gold and silver mines. ${ }^{73}$

Beginning in the second half of the $18^{\text {th }}$ century, the new anthropological and philosophical interest in the colonial 'Others', -- their cultures and societies, and especially their discourses and voices, their testimonies and the world-view they were supposed to represent -

\footnotetext{
${ }^{70}$ POMA DE AYALA, Felipe Guamán. Nueva Corónica y Buen Gobierno (codex péruvien illustré), edición facsimilar de Paul River. Paris: 1936, quoted in : PORTILLA, Miguel León Portilla. El reverso de la conquista. Relaciones aztecas, mayas e incas. México: Editorial Joaquin Mortiz, 1964, 3ra ed. 1964, p. 117. See on POMA DE AYALA and his ideological positions: BARRENECHEA, Raúl Porras. Los cronistas del Perú, 1528-1650) y otros ensayos. Edición, prólogo y notas de Franklin Pease G.Y. Bibliografía de Félix Alvarez Brun y Graciela Sánchez Cerro, revisada, aumentada y actualizada por Oswaldo Holguín Callo. Lima : Editorial e Imprenta DESA, 1986 (Biblioteca Clásicos del Perú/2), p. 615-663 («El Cronista indio Felipe Huaman Poma de Ayala, 1534$1615 »)$

${ }^{71}$ Ibid, p. 117. Translation: « Here, with these gentile Indians, they are against our faith ! »

${ }^{72}$ See on this point some remarks by LAVALLÉ. Pizarro, p. 146-147: « Il [the event of Cajamarca] est surtout la preuve de ce que les dignitaires incas, issus d'un autre monde, empreints d'une autre mentalité, jugeant d'après d'autres paramètres, ne pouvaient même pas imaginer. »

${ }^{73}$ BARRENECHEA, Raúl Porras. El cronista indio Felipe Huaman Poma de Ayala. Lima: Editorial Lumen, 1948, annex, p. XIV.
}

Jangada| ano 9, nr. 17, jan/jun, 2021 | ISSN 2317-4722 265 |P á g i n a 
and also generated - a re-discovery and a re-reading of the intercultural situations, dialogues and conflicts of the conquest of America. Some of the main representatives of the political philosophy of the Enlightenment - Robertson in England, Herder and Forster in Germany, Marmontel, Prévost and Raynal in France - profoundly re-interpreted the history of the discovery and the conquest of America in denouncing the crimes of the Spaniards, in putting into question their discourses and historiographical representations, in de-legitimizing the violence of the conquest and in trying to integrate the visions and the world-views of the 'discovered' and subsequently colonized populations and societies. ${ }^{74}$ The most important texts they referred to were the Commentarios reales and the Historia de las Incas written by Garcílaso de la Vega (1539-1619). Written and partially published at the end of the 16th century, Garcilaso's work was widely re-discovered, re-edited, translated and commented upon during the 18th century, because of its new and intense interest in the world-views of other civilizations. In some ways, this 16th century author became a formative figure of the Enlightenment because of the completely new reception of his work in the 18th century, especially in France, England and in Germany.

With regard to the role and the functions of the cultural broker, the multiple discourses on the events of November $16^{\text {th }}, 1532$ reveal a multilayered complexity. Translators and translation processes play an important role: from the interactions in Cajamarca and the dilettantish efforts of the Peruvian translator Felipillo to the translations of the Spanish and Italian chronicles of the $16^{\text {th }}$ and early $17^{\text {th }}$ centuries (Benzoni, Zárate, Garcilaso de la Vega) in other European languages, especially French and English, which often served as the basis for translations in other languages (like German, Dutch and Swedish). A closer look at these translation processes reveals that they are always related to forms of commentary, rewriting, reinterpretation and re-semantization, but also to forms of misunderstandings and strategies of manipulation. The broad scope of cultural brokers (or mediators) related to the event of Cajamarca and its discursive transmission also shows the role of indigenous languages and the world view they are based on. Like a 'return of the repressed', this dimension reappeared with the work of Inca Garcilaso de la Vega and, far later, with the accounts by Poma de Ayala, both of whom were mestizos educated in both Spanish and Inca cultures and languages. They

\footnotetext{
${ }^{74}$ See also on this point WACHTEL, Nathan. La vision des vaincus. Les Indiens du Pérou devant la Conquête espagnole, 1530-1570. Paris: Gallimard, 1971, p. 6770 (on Atahualpa and the Cajamarca event), p. 245-247 (on Poma de Ayala), p. 244-245 (on Garcilaso de la Vega).
}

Jangada | ano 9, nr. 17, jan/jun, 2021 | ISSN 2317-4722 


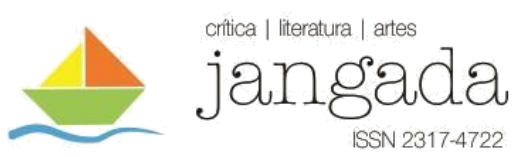

represented a new role for the cultural mediator which would have a decisive impact also on the reinterpretation of both the violence and the communicative acts that arose out of the encounter between Pizarro, Valverde and Atahualpa in 1532.

\section{BIBLIOGRAPHICAL REFERENCES}

Archivio de las Indias, Sevilla, Manuscript Información de Francisco Atahualpa.

BARRENECHEA, Raúl Porras. Los cronistas del Perú, 1528-1650) y otros ensayos. Edición, prólogo y notas de Franklin Pease G.Y. Bibliografía de Félix Alvarez Brun y Graciela Sánchez Cerro, revisada, aumentada y actualizada por Oswaldo Holguín Callo. Lima: Editorial e Imprenta DESA, 1986.

El cronista indio Felipe Huaman Poma de Ayala. Lima: Editorial Lumen, 1948.

BENZONI, Girolamo. Historia del Mondo Nuovo. Einleitung Ferdinand Anders. Zweite ergänzte und erweiterte Ausgabe. Graz, Akademische Druck-und Verlagsanstalt, 1969.

. History of the New World, shewing his travels to America, from A.D. 1541 to 1556, with some particulars on the island of Canary. Now first translated, and edited by Rear-Admiral W.H. Smyth. London: Printed for the Haklyut Society, 1857.

Historia del Mondo Nuovo. Venetia: Pietro \& Francesco Tini, 1572, Lib. III. (Reprinted in Graz, Akademische Druck- und Verlagsanstalt, 1969.

BERTRAND, Carmen; GRUZINSKI, Serge. Histoire du nouveau monde. De la découverte à la conquête, une expérience européenne, 1492-1550. Paris : Fayard. 1991.

BERTRAND, Carmen. Un Inca platonicien. Garcilaso de la Vega 1539-1616. Paris : Fayard, 2006.

CANCLINI, Néstor García. Culturas híbridas: Estrategias para entrar y salir de la modernidad. México: Grijalbo, 1990.

Hybrid Cultures: Strategies for Entering and Leaving Modernity. Minneapolis:

University of Minnesota Press, 1995.

CIEZA DE LEÓN, Pedro. The Discovery and Conquest of Peru. Chronicles of the New World Encounter. Edited and Translated by Alexandra Parma Cook and Noble David Cook. Durham/London: Duke University Press, 1998

DE BRY, Theodor. Kolumbus wird, als er zum ersten mal in Indien angekommen ist, von den Einwohnern mit großen Geschenken verehret und begabet aufgenommen. Engraving on copper, 1594 ("Columbus landing on Hispaniola"). (https://commons.wikimedia.org/wiki/File:Columbus_landing_on_Hispaniola_adj.jpg”). DELHOUME-SANCIAUD, Monique. «Les Incas ou la destruction de l'Empire du Pérou » de Jean-François Marmontel. Paris: Honoré Champion, 2017, vol. II.

FORSTER, Georg. Sämtliche Schriften, Tagebücher, Briefe. Vol. XI : Rezensionen. Bearbeitet von Horst Fiedl. Berlin: Akademie-Verlag, 1977. 


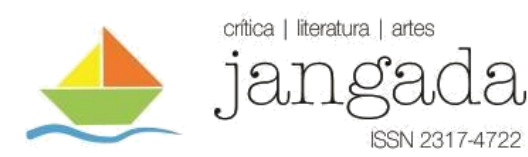

GRUZINSKI, Serge. Visions indiennes, visions baroques. Les métissages de l'inconscient. Paris: PUF, 1992.

The Mestizo Mind: The Intellectual Dynamics of Colonization and Globalization. London: Routledge, 2002.

. Les quatre parties du monde. Histoire d'une mondialisation. Paris : Éditions de La Martinière, 2004.

KOHUT, Karl; TORALES PACHECO, María Cristina (eds.). Desde los confines de los imperios ibericos. Los jesuitas de habla alemana en las misiones americanas. Frankfurt, Vervuert-Verlag/ Madrid: Iberoamericana-Verlag, 2007.

KOSELLECK, Reinhart. Vergangene Zukunft. Zur Semantik geschichtlicher Zeiten. Frankfurt/Main: Suhrkamp, 2003.

. Future's Past: on the Semantics of Historical Times. New York: Columbia University Press, 2004.

LAVALLÉ, Bernard. Francisco Pizarro, conquistador de l'extrême. Paris: Payot, 2004.

LÓPEZ DE GÓMORA, Francisco. Historia General de las Indias y Vida de Hernán Cortes (1552). Prólogo y Cronología de Jorge Gurria Lacroix. Venezuela: Biblioteca Ayacucho, 1979. LÜSEBRINK, Hans-Jürgen. Comprehensión y malentendidos interculturales en las obras de Baegert (Noticias de la península americana California) y Dobrizhoffer (Historia de los Abipones).

MARMONTEL, Jean-François. Les Incas, ou la destruction de l'Empire du Pérou. Texte établi et présenté par Pierino Gallo. Paris : Société des Textes Français et Modernes, 2016.

. Les Incas ou la destruction de l'empire du Pérou. Liège: Bassompierre, 1777, vol.

II.

Les Incas, ou la destruction de l'Empire du Pérou. Paris : Lacombe, 1777, 2 vols.

The Incas, or The Destruction of the Empire of Peru. Dublin: Messrs. Price,

Whitestone, 1777, 2 vols.

MIDDELL, Matthias. (ed.): The Routledge Handbook of Transregional Studies. London/New York, Routledge, 2019.

POMA DE AYALA, Felipe Guamán. Nueva Corónica y Buen Gobierno (codex péruvien illustré), edición facsimilar de Paul River. Paris: 1936.

PORTILLA, Miguel León Portilla. El reverso de la conquista. Relaciones aztecas, mayas e incas. México: Editorial Joaquin Mortiz, 1964

PRÉVOST, Abbé. Histoire générale des voyages, Paris : Didot, 1752, t. 49.

QUEIJA/ARES, Berta; GRUZINSKI, Serge. (eds.). Entre dos mundos.Sevilla: Fronteras Culturales y Agentes Mediadores, 1997.

RAYNAL, Guillaume-Thomas. Histoire philosophique et politique des établissemens et du commerce des Espagnols dans les deux Indes. Neuchâtel et Genève : Chez les Libraires Associés, 1783, vol. III.

. Histoire philosophique et politique des établissemens et du commerce des Espagnols dans les deux Indes. Édition critique. Sous la direction de Anthony Strugnell, Gianluigi Goggi

Jangada | ano 9, nr. 17, jan/jun, 2021 | ISSN 2317-4722 


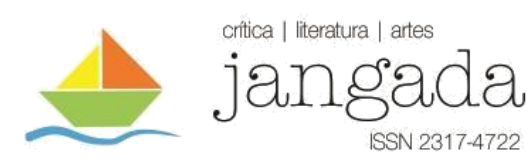

and Kenta Ohji. Tome II. Livres VI à IX. Sous la direction de Andrew Brown et Hans-Jürgen Lüsebrink. Ferney-Voltaire : Centre International d'Étude du XVIIIe siècle, 2018.

ROBERTSON, William. The History of America. By William Robertson, Principal of the University of Edinburgh, and Historiographer to his Majesty for Scotland. London: Printed for W. Strahan, T. Cardell, J. Balfour, 1777, 2 vols.

STERLING, Stuart. Pizarro, Conqueror of the Inca. Phoenix Mill: Sutton Publishing, 2005.

TOSI, Carlo Angelo. Un Milanese nel nuovo mundo. Le Indie di Girolamo Benzoni. Zermeghedo: Edizioni Saecula, 2017.

TRUJILLO, Diego de. Una relación inedita de la conquista. La Crónica de Diego de Trujillo. Lima; Miraflores: Ed. by Raúl Porras Barrenechea. Lima, 1970.

VEGA, Inca Garcilaso de la. Primer aparte de los Commentarios reales que tratan de los Yncas, reyes que fieron del Perú, de su idolatría, leyes y gobierno en paz y en guerra, de sus vidas y conquistas y de todo lo que fue aquel Imperio y su república antes que los españoles passaran a él. Lisboa: Pedro Crasbeck, 1609.

The Royal Commentaries of Peru, in two parts. First translation London, by Paul Ricaut, 1708. Edition quoted here: London, by Miles Flesher, for Christopher Wilkinson, 1788, vol. II.

WACHTEL, Nathan. La vision des vaincus. Les Indiens du Pérou devant la Conquête espagnole, 1530-1570. Paris: Gallimard, 1971.

ZÁRATE, Augustín de. The Discovery and Conquest of Peru. Translated and with an Introduction by J.M. Cohen. London: Penguin Books, 1968.

. Historia dle descubrimiento y conquista del Peru. Anvers : Matin Nucio, 1555.

French translation: ZARATE, Augustín de. Histoire de la découverte et de la conquête du Pérou. Traduite de l'espagnol. Paris : Compagnie des Libraires, 1774, 2 vol. 